\title{
THE GROWTH IN VITRO OF VACCINIA VIRUS IN CHICK EMBRYO CHORIO-ALLANTOIC MEMBRANE, MINCED EMBRYO AND CELL SUSPENSIONS
}

\author{
By H. B. MAITLAND AND D. I. MAGRATH* \\ Department of Bacteriology, University of Manchester
}

(With 8 Figures in the Text)

The behaviour of vaccinia virus after its inoculation on the chorio-allantoic membrane of the developing chick embryo was described in detail by Maitland \& Tobin (1956). In assessing the total amount of virus that could be recovered it was necessary to titrate the liquid, which, during the process of harvesting the membrane, collected in the shell when the membrane was detached and removed, as well as to titrate virus in the membrane itself. Immediately after inoculation the amount of virus recovered from both sources, estimated by pock-counts, was greater than the amount inoculated (termed enhancement of infectivity). At first most of the virus was in the liquid, but during incubation of the egg it gradually passed from the liquid to the membrane. As a consequence the amount of virus in the membrane rose for a time, but concurrently some loss of virus occurred so that the amount in the membrane itself at a particular time depended upon a balance between accumulation and loss; the amount rose for about an hour and then began to fall. The total amount of virus however decreased gradually from the start and reached a minimum in $2-3 \mathrm{hr}$. being then $20 \%$ or more of the amount detected immediately after inoculation (i.e. allowing for initial enhancement). Increase of virus due to growth was detected 4-5 hr. after inoculation.

Anderson (1954) noted a gradual loss of infectivity of vaccinia virus, after inoculation on the chorio-allantoic membrane; during the first $9 \mathrm{hr}$. about $90 \%$ disappeared. At $10 \mathrm{hr}$. the titre had begun to rise and it increased steadily from then onwards. Additional observations led to the conclusion that the majority of the inoculated virus entered an 'eclipse phase' during the first $9 \mathrm{hr}$., the implication being that it went through a non-infective stage as part of a cycle of multiplication. This, however, was an assumption for there was no conclusive evidence to indicate whether the newly formed virus was derived from that part of the inoculum which became non-infective or from the part which retained its infectivity. Either was possible. Briody \& Stannard (1951) using egg-passaged virus noted a very marked drop in infectivity of virus during the first hour after inoculation on the chorio-allantoic membrane, a latent period up to $8 \mathrm{hr}$., with a sudden large increase of virus at that time and another steep rise in titre at about $16 \mathrm{hr}$. These findings were interpreted as indicating that a major change in the virus particle, masking its infectivity, was part of a growth cycle. Again, this was an assumption and no further experiments were made in support of it.

* In receipt of a Medical Research Council Scholarship. 
The shape of the curve of changes in titre reported by Anderson differed from that of Briody \& Stannard in showing a gradual preliminary fall during $9 \mathrm{hr}$. instead of a steep fall for $1 \mathrm{hr}$. and in showing a steady and continuous increase instead of step-wise increments.

Crawford \& Sanders (1952) cultured the virus in thin pieces of skin, removed from a rabbit's ear after intradermal inoculation, by incubating them in a nutrient medium. There was a decline in infectivity during the first few hours of incubation and a rise in titre after about $10 \mathrm{hr}$.

In order to avoid the complexity of the conditions in vivo, experiments to be reported here were made $i n$ vitro, using chorio-allantoic membranes, minced chickembryo or cell suspensions, which enabled contact between tissue or cells and virus to be controlled and ensured that changes in infectivity of virus were due to processes taking place in or on the tissue or cells.

\section{MATERIALS AND METHODS}

The strain of virus was that used at the Lister Institute for preparing small pox vaccine. It was repeatedly passed in the skin of rabbits. Elementary body suspensions were prepared from infected rabbit skin by the method of Hoagland, Smadel \& Rivers (1940); they were stored at -20 to $-40^{\circ} \mathrm{C}$. and thawed only once, immediately before use. Virus was titrated by inoculating $0.05 \mathrm{ml}$. of tenfold dilutions on the chorio-allantoic membrane of eggs incubated for 12-13 days. Eight eggs were used for each dilution. They were incubated further at $37^{\circ} \mathrm{C}$. for 2 days when pock counts were made. The infectivity was expressed as the number of pocks (infective units of virus) per $\mathrm{ml}$.

\section{GROWTH-CURVE EXPERIMENTS}

\section{Ghorio-allantoic membranes}

\section{Experimental procedures}

Chorio-allantoic membranes were removed from eggs that had been incubated for 12-13 days by detaching the membrane from a piece of shell which had been cut around and separated from the egg (as in harvesting membranes for pockcounting). Each membrane was put into $1 \mathrm{ml}$. of a known amount of virus and kept at $37^{\circ} \mathrm{C}$. for $10 \mathrm{~min}$. with frequent gentle agitation by hand. The membranes were removed and washed in pairs in $10 \mathrm{ml}$. of Hanks' solution in a $25 \times 150 \mathrm{~mm}$. test tube which was held against an eccentric rapidly rotating rubber bung so that the bottom of the tube made about 400 double excursions of about $3 \mathrm{~cm}$. amplitude during $1 \mathrm{~min}$. The membranes swirled around rapidly in the tube during this time. They were transferred to a similar tube and the washing repeated. Some membranes were then ground and titrated as a base line of infectivity. Others were put in pairs into a shallow layer of Hanks' solution $(4 \mathrm{ml}$. in a $50 \mathrm{ml}$. conical flask) and incubated at $37^{\circ} \mathrm{C}$. in air, to be ground and titrated at intervals. The experiments were arranged so that the product of four similar membranes was pooled for each titration; the membranes were disintegrated in a Griffiths' tube as 
described by Maitland \& Tobin (1956). Tissue suspensions and dilutions of all materials for titration were made in Hanks' solution.

\section{Results}

Enhancement of infectivity of virus occurred when a membrane was put into a suspensions of virus in order to infect it. The amount of virus in the membrane after contact plus the amount left in the suspension was usually greater than the original amount of virus. This, however, was incidental to the present experiments and did not affect the validity of the base line titration.

The amount of virus in membranes after they had been in contact with virus and drained of excess of virus, but before they were washed, ranged between 20 and $40 \%$ of the original titre of virus in the tube. After washing, which was intended to remove virus loosely adherent to the membrane in a surface film of liquid, and to leave only virus which was firmly attached to the tissue, the amount of virus on the membrane was usually $5-10 \%$ of the virus originally in the suspension.

A similar result was obtained if contact was at room temperature, about $18^{\circ} \mathrm{C}$. Contact for longer periods up to $60 \mathrm{~min}$. did not result in appreciably greater adsorption. The period of contact for $10 \mathrm{~min}$. was thus adequate and, in determining a base line of infectivity, was preferable to a longer period because it avoided the possibility of longer contact resulting in loss of infectivity of the virus in the membrane. The base line in these experiments thus represented virus firmly attached to the tissue and it was determined before any appreciable loss of infectivity was likely to have occurred.

The changes in titre of virus in the membrane during incubation in vitro were of the same kind as occurred in vivo but they took place more slowly.

The data for three typical experiments are shown in Table 1. By titrating at relatively short intervals, the trend of change in titre became evident although a few individual figures were out of line. The curves of change in titre are shown in Fig. 1. There was gradual loss of infectivity for approximately $10 \mathrm{hr}$. At the lowest point the virus that remained was $25 \%$ or more of the amount present in the membrane at the start. Increase was clearly detectable at 18-20 hr., and began earlier in some experiments. No clear evidence for step-wise increases was obtained but the experiments were not designed to study this point. Similarly, it was not possible to deduce the exact time at which multiplication of virus began in individual cells. Although all the cells that were originally infected must have become infected within a period of about $10 \mathrm{~min}$. the speed of events taking place within the cells may not have been uniform. Further, the change from a falling to a rising titre depends on the balance between continuing loss and start of growth of virus in the membrane as a whole.

These results agree with those obtained in vivo (Maitland \& Tobin, 1956) in demonstrating a similar loss of infectivity prior to multiplication and in confirming that this loss occurred in the membrane. In both sets of experiments at least $20-25 \%$ of virus, sometimes more, remained infective. The lowest point of infectivity and the time when virus began to increase occurred later in vitro than in vivo. 
Table 1. Changes in titre* of virus in chorio-allantoic membranes incubated in Hanks' solution

incubation

\begin{tabular}{ccc}
\multicolumn{3}{c}{ Experiment } \\
$\overbrace{39}$ & 40 & 42 \\
100 & 100 & 100 \\
$(29,000) \dagger$ & $(28,800) \dagger$ & $(31,800) \dagger$ \\
- & - & 88 \\
- & 77 & 106 \\
- & - & 67 \\
26 & 82 & - \\
35 & 24 & - \\
46 & 33 & 29 \\
120 & 42 & 35 \\
107 & 24 & 55 \\
386 & 70 & 27 \\
414 & 84 & 540 \\
- & - & 143 \\
770 & 560 & - \\
725 & 810 & 396
\end{tabular}

* Expressed as percentage of the titre at $0 \mathrm{hr}$.

$\dagger$ Number of infective units of virus (pocks) per membrane at $0 \mathrm{hr}$.



Fig. 1. Growth curves of vaccinia virus in chorio-allantoic membranes incubated in Hanks' solution. 
The virus remained almost entirely in the membrane. In one experiment after incubation for $6 \mathrm{hr} ., 3 \%$ of the total virus in the flask was in the medium, and after $20 \mathrm{hr}$. only $0 \cdot 3 \%$.

\section{Heated and disintegrated chorio-allantoic membranes Experimental procedures}

In order to obtain further evidence which might help to decide whether the initial fall in titre of virus in membrane was or was not an essential part of virus reproduction, experiments were made, similar to those described in the previous section, but using heated and disintegrated membranes in which the virus would not grow.

Heated membranes. Membranes were immersed in Hanks' solution and heated in a water-bath before being put in contact with virus. Exposure to $45^{\circ} \mathrm{C}$. for $20 \mathrm{~min}$. followed by contact with virus, washing and incubation, as in the previous experiments, did not prevent growth of virus which occurred in less than $20 \mathrm{hr}$. Heating at $45^{\circ} \mathrm{C}$. for $40 \mathrm{~min}$. also failed to abolish the growth of virus, but it began later and was detectable between 24 and $48 \mathrm{hr}$. When membranes were heated at $50^{\circ} \mathrm{C}$. for $20 \mathrm{~min}$. there was no growth of virus; after $48 \mathrm{hr}$. incubation the titre of the virus was declining. This amount of heating was therefore adopted as the minimum that would abolish growth of virus and in what follows this is connoted by the term 'heated membranes'.

Heated membranes were exposed to virus, washed, incubated and titrated as described for normal membranes.

Disintegrated membranes. Normal membranes were put in contact with virus as in the growth-curve experiments. They were then washed, as described, placed in chilled Hanks' solution ( $2 \mathrm{ml}$. per membrane) and disintegrated in an 'atomix' blender * running at full speed for $2 \frac{1}{2} \mathrm{~min}$. From fourteen to sixteen membranes were disintegrated at one time; the Hanks' solution and the head of the machine were chilled to avoid producing a temperature which might harm the virus during the operation. The temperature did not rise above $21^{\circ} \mathrm{C}$. There was almost total disruption of cells; at most only a few intact cells could be seen. The suspension of disintegrated infected tissue was incubated in $50 \mathrm{ml}$. conical flasks, $4 \mathrm{ml}$. per flask, the proportion of tissue and medium being the same as with intact membranes; the equivalent of four membranes was pooled and titrated at intervals.

Heated and disintegrated membranes. Heated membranes were exposed to virus, washed, disintegrated, incubated and titrated as described for the previous experiments.

\section{Results}

Heated membranes absorbed as much virus as normal membranes so that the base lines of infectivity, after washing and before incubation, were quantitatively comparable. During the first $10 \mathrm{hr}$. of incubation the fall in titre of virus in heated membranes was similar, both in rate and amount, to the fall which preceded

* Made by Measuring and Scientific Equipment Ltd., London. 
growth of virus in normal membranes, but, instead of the subsequent rise in titre due to growth, the virus in heated membranes continued to decrease. With disintegrated membranes the rate of fall in $10 \mathrm{hr}$. was somewhat less and with membranes which were both heated and disintegrated it was intermediate. After about $10 \mathrm{hr}$. the rate of fall in all the experiments became much slower; a considerable amount of virus remained at $48 \mathrm{hr}$. and in experiment 71 , the only one tested after longer incubation, virus was found after 6 days (Table 2 and Fig. 2).

Table 2. Changes in titre* of virus in heated or disintegrated chorio-allantoic membranes incubated in Hanks' solution

\begin{tabular}{|c|c|c|c|c|c|c|}
\hline \multirow{2}{*}{$\begin{array}{l}\text { Hours of } \\
\text { incubation }\end{array}$} & \multicolumn{2}{|c|}{$\begin{array}{c}\text { Heated } 50^{\circ} \mathrm{C} . \\
20 \mathrm{~min} . \\
\text { Experiment }\end{array}$} & \multicolumn{2}{|c|}{$\begin{array}{l}\text { Disintegrated. } \\
\text { Experiment }\end{array}$} & \multicolumn{2}{|c|}{$\begin{array}{c}\text { Heated and } \\
\text { disintegrated. } \\
\text { Experiment }\end{array}$} \\
\hline & 66 & 69 & 70 & 71 & 73 & 75 \\
\hline 0 & $\begin{array}{c}100 \\
(23,500) \dagger\end{array}$ & $\begin{array}{c}100 \\
(36,400) \dagger\end{array}$ & $\begin{array}{c}100 \\
(61,700) \dagger\end{array}$ & $\begin{array}{c}100 \\
(4,800) \dagger\end{array}$ & $\begin{array}{c}100 \\
(8,500) \dagger\end{array}$ & $\begin{array}{c}100 \\
(32,980) \dagger\end{array}$ \\
\hline 1 & 117 & 30 & 88 & 92 & 85 & 86 \\
\hline 3 & 52 & 71 & 78 & 72 & 73 & 39 \\
\hline 5 & 10 & 27 & 67 & 59 & 57 & 29 \\
\hline 9 & - & - & - & - & 51 & 37 \\
\hline 10 & 13 & 30 & 69 & 25 & - & - \\
\hline 24 & 12 & 44 & 45 & 61 & 60 & 58 \\
\hline 48 & 12 & 6 & 47 & 40 & 31 & 28 \\
\hline 6 days & - & - & - & 4 & - & - \\
\hline
\end{tabular}

* Expressed as percentage of the titre at $0 \mathrm{hr}$.

$\dagger$ Number of infective units of virus (pocks) per membrance at $0 \mathrm{hr}$.

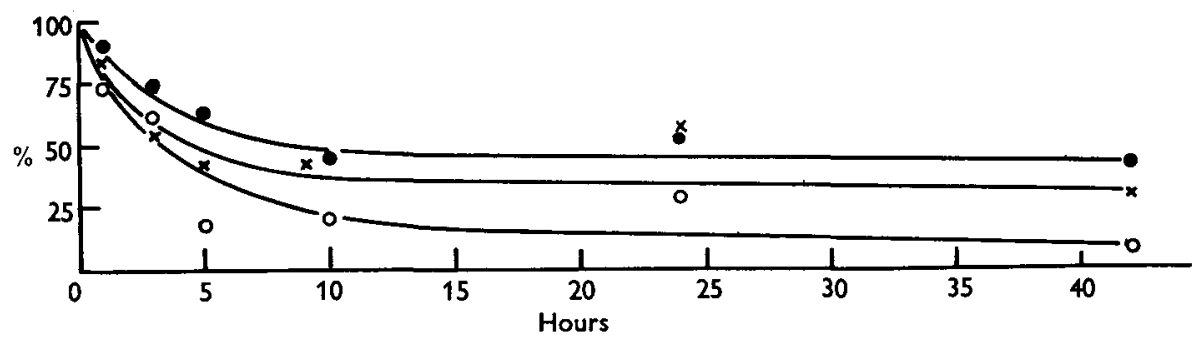

Fig. 2. Changes in infectivity of vaccinia virus incubated in heated and disintegrated membranes. Each curve represents the average of two experiments. $O$, heated; 9 , disintegrated; $\times$, heated and disintegrated.

\section{Minced chick-embryo}

Embryos, 12 days' old, less the head and legs, were finely minced with scissors. The mince was washed successively in two lots of $10 \mathrm{ml}$. Hanks' solution per embryo; after mixing it was allowed to settle by gravity. The washed tissue was infected by adding to 1 vol. mince, 1 vol. virus and 3 vol. Hanks' solution, and keeping this at room temperature for $10 \mathrm{~min}$. with gentle agitation by hand. The mince was then allowed to settle and washed twice, each in 5 vol. of Hanks' solution, by mixing and settling under gravity. One volume of infected and 
washed mince was mixed with 19 vol. Hanks' solution, distributed in $5 \mathrm{ml}$. amounts to $2 \frac{1}{2}$ in. Petri dishes and incubated in air at $37^{\circ} \mathrm{C}$. At intervals the tissue was ground in a Griffiths' tube, mixed with the liquid part of the culture, and titrated.

The results of two typical experiments are shown in Table 3. In general they corresponded with those obtained for chorio-allantoic membranes; there was a marked fall in titre for about $10 \mathrm{hr}$. to 30-40\% of the original titre, and in 24-26 hr. a clear indication that growth had occurred.

\section{Table 3. Changes in titre* of virus in minced chick-embryo incubated in Hanks' solution}

$\begin{array}{ccc}\begin{array}{c}\text { Hours of } \\ \text { incubation }\end{array} & \overbrace{129}^{2} \text { Experiment } \\ 0 & 100 & 133 \\ & (24,000) \dagger & 100 \\ 2 & 73 & (3920) \dagger \\ 4 & 57 & 67 \\ 6 & 40 & 35 \\ 8 & 35 & 77 \\ 10 & 47 & 29 \\ 12 & - & 43 \\ 24 & 63 & 92 \\ 26 & 254 & 290 \\ 28 & 350 & 510 \\ 30 & 527 & 780 \\ 48 & 2900 & 1350 \\ & & 14600\end{array}$

* Expressed as percentage of the titre at $0 \mathrm{hr}$.

$\uparrow$ Number of infective units of virus (pocks) per ml.

\section{Chick-embryo cell suspensions \\ Experimental procedures}

Twelve-day-old embryos less head and legs were minced and washed twice in $4 \mathrm{ml}$. Hanks' solution per embryo by mixing and allowing the tissue to settle. To the deposit, $8 \mathrm{ml}$. per embryo of $0.25 \%$ Difco trypsin in phosphate-buffered saline (Dulbecco \& Vogt, 1954) was added and allowed to act for $10 \mathrm{~min}$. at $37^{\circ} \mathrm{C}$. with agitation at intervals. The suspension of cells thus obtained was filtered through a 100 mesh per inch gauze. The cells were then deposited in a horizontal centrifuge at 1000 r.p.m. for 5 min., washed by similar deposition three times from equivalent volumes of Hanks' solution, and finally suspended in Hanks' solution to give $10 \times 10^{6}$ cells per $\mathrm{ml}$. To this $1 / 20$ volume of a suitable dilution of virus in Hanks' solution was added. Contact was for $10 \mathrm{~min}$. at $37^{\circ} \mathrm{C}$. The cells were again deposited and the supernatant fluid removed. The deposit was resuspended in culture medium to contain $2 \times 10^{6}$ cells per ml. and distributed in $6 \mathrm{ml}$. amounts to $2 \frac{1}{2}$ in. Petri dishes which were incubated in air at $37^{\circ} \mathrm{C}$. The medium unless otherwise specified was $20 \%$ chick-embryo extract and $0.5 \%$ casein hydrolysate (enzymatic) in Hanks' solution. 
For titration the supernatant fluid was removed from a Petri dish and $2 \mathrm{ml}$. of $0.25 \%$ Difco trypsin in phosphate-buffered saline added and allowed to act for $10 \mathrm{~min}$. at $37^{\circ} \mathrm{C}$. This was required to detach the cells from the glass, particularly when they had stuck after a few hours of incubation. (As the trypsin had the effect of increasing somewhat the titre of the virus (see Maitland \& Tobin, 1956), it was allowed to act similarly on the controls which were samples of the bulk culture, as distributed into Petri dishes before incubation). The trypsin plus detached cells was added to the supernatant fluid and the dish washed out with $4 \mathrm{ml}$. Hanks' solution plus a volume equal to any loss of fluid during incubation of the culture. The cells from this $12 \mathrm{ml}$. of material were deposited in an angle centrifuge and the supernatant fluid put on one side. The deposit was resuspended in $12 \mathrm{ml}$. Hanks' solution and treated in an M.S.E. 'masticator' for 5 min. to break up the cells. The material was in a $25 \mathrm{ml}$. universal container and the machine was run at full speed; over $95 \%$ of the cells were disintegrated. The treatment had no effect on the titre of virus in Hanks' solution. The cells were masticated in Hanks' solution to avoid excessive frothing which occurred with the culture medium. The masticated cells were then added to the supernatant fluid from the last centrifuging, making a volume of $24 \mathrm{ml}$. which was titrated.

Freshly prepared cells were used for most experiments, but cells kept overnight at $4^{\circ} \mathrm{C}$. were found to be satisfactory. During preparation sometimes a small amount of clumping occurred, but the clumps could be readily dispersed or removed by refiltering through the metal gauze; the suspensions used for the experiments were practically free from clumps, at most only an occasional small microscopic clump was present. In the Petri dish the cells settled, and many stuck to the glass, spread out and multiplied if the cultures were incubated long enough, but only a small proportion (about $1 \%$ ) of the cells was infected at the beginning of the experiment. The cells in the suspension were obviously not all of the same type, as was to be expected, nor were they uniform as regards their physiological intactness as many cells, although morphologically apparently healthy, failed to stick to the glass and became rounded and granular. The number of infected cells could be determined by titrating the cell suspension unmasticated and thus the percentage of cells originally infected was estimated.

In order to avoid as far as possible difficulties in interpreting the results of titration owing to variability inherent in the technique three precautions were taken; $(a)$ titrations at frequent intervals were made so that a trend would be apparent even if an occasional reading was out of line; $(b)$ two or even three controls were put up and titrated separately and the average taken as a base line; (c) for each reading duplicate cultures were titrated separately and the average taken.

\section{Results}

In the system of cells and medium used for these experiments the fall in titre of virus which preceded growth was relatively small, and in this respect differed from the behaviour of the virus in chorio-allantoic membranes and minced embryo. The data for representative experiments are in Table 4 and Figs. 3-8. In a number 
of experiments the level of virus remained at $85-90 \%$ of the original titre until growth began and in the others it seldom fell below 65-70\%; only in an occasional experiment did the titre drop to $40-50 \%$.

Table 4. Changes in titre* of virus in chick-embryo cell suspensions incubated in nutrient medium

\begin{tabular}{|c|c|c|c|c|c|}
\hline \multirow{2}{*}{$\begin{array}{l}\text { Hours of } \\
\text { incubation }\end{array}$} & \multicolumn{5}{|c|}{ Experiment } \\
\hline & 147 & $148 \ddagger$ & $149 \S$ & $150 \S$ & $153 \|$ \\
\hline 0 & $\begin{array}{c}100 \\
(19,600) \dagger\end{array}$ & $\begin{array}{c}100 \\
(8,400) \dagger\end{array}$ & $\begin{array}{l}100 \\
(23,700) \dagger\end{array}$ & $\begin{array}{c}100 \\
(6,600) \dagger\end{array}$ & $\begin{array}{c}100 \\
(24,500) \dagger\end{array}$ \\
\hline 1 & 68 & 90 & 106 & 70 & 84 \\
\hline 2 & 73 & 83 & 90 & 82 & 76 \\
\hline 3 & 76 & 56 & 83 & 115 & 77 \\
\hline 4 & 74 & 95 & 118 & 65 & 98 \\
\hline 5 & 77 & 58 & 112 & 57 & 97 \\
\hline 6 & 55 & 40 & 108 & 81 & 98 \\
\hline 7 & 72 & 55 & 99 & 78 & 88 \\
\hline 8 & 70 & 73 & 83 & 104 & 104 \\
\hline 9 & 70 & 53 & 68 & 69 & - \\
\hline 10 & - & - & 83 & - & - \\
\hline 11 & - & - & 123 & 60 & - \\
\hline 12 & 91 & - & - & - & - \\
\hline 14 & 82 & - & - & - & - \\
\hline 16 & 98 & - & - & - & - \\
\hline 22 & 134 & - & - & - & - \\
\hline 23 & - & 220 & 276 & 260 & - \\
\hline 24 & 168 & - & - & - & - \\
\hline 25 & - & 366 & 320 & 266 & - \\
\hline 28 & 338 & 585 & 450 & - & - \\
\hline 30 & 415 & 730 & 480 & 1080 & - \\
\hline \multirow[t]{2}{*}{48} & 5700 & - & - & - & $>3000$ \\
\hline & $\begin{array}{l}\text { Expresse } \\
\text { Number } \\
\text { The figur } \\
\text { The figur } \\
\text { The figur }\end{array}$ & $\begin{array}{l}\text { ercentag } \\
\text { s per ml. } \\
\text { r. is the } \\
\text { ir. is the } \\
\text { aghout a }\end{array}$ & $\begin{array}{l}\text { e titre at } \\
\text { r. } \\
\text { e of } 2 \mathrm{con} \\
\Theta \text { of } 3 \mathrm{titr} \\
\text { average of }\end{array}$ & $\begin{array}{l}\text { ations. } \\
\text { te titra }\end{array}$ & \\
\hline
\end{tabular}

The fall in titre that did occur was gradual, the period of lowest values occurring between 5 and $10 \mathrm{hr}$. The infective titre of the cultures usually began to increase between 15 and $20 \mathrm{hr}$., which was confirmed by other titrations made especially to cover the period between 16 and $24 \mathrm{hr}$., and at $24-45 \mathrm{hr}$. it was rapidly rising.

Observations made specially to detect any rapid or extensive loss of virus during the first $90 \mathrm{~min}$. following contact between virus and cells failed to reveal any such occurrence. Thus the control titrations represented a proper base line as no rapid loss of virus occurred during the manipulations required to prepare the controls for titration.

The medium in which the cells and virus were incubated affected the outcome. In two experiments in which infected cells were incubated in Hanks' solution the virus declined to about $30 \%$ of the original amount in $5-10 \mathrm{hr}$. and to $10-15 \%$ in $24 \mathrm{hr}$. In two experiments $20 \%$ chick-embryo extract in Hanks' solution was 
used; in one the level of virus remained at about $90 \%$ of the original amount and in the other at $75-80 \%$ during the preliminary period; in both experiments growth began somewhat later than when the chick embryo cells were present in the culture medium.

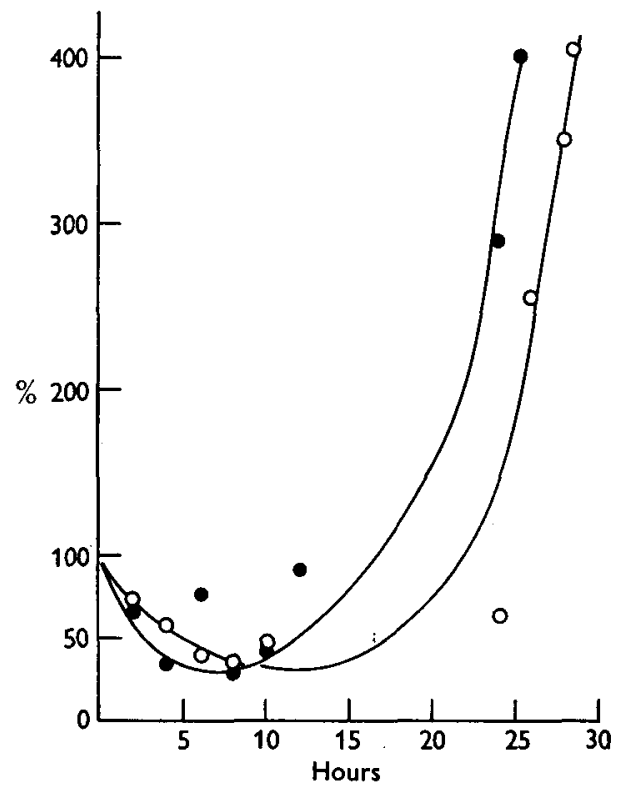

Fig. 3. Growth of vaccinia virus in minced chick-embryo incubated in Hanks' solution.



Fig. 4. Experiment 147.

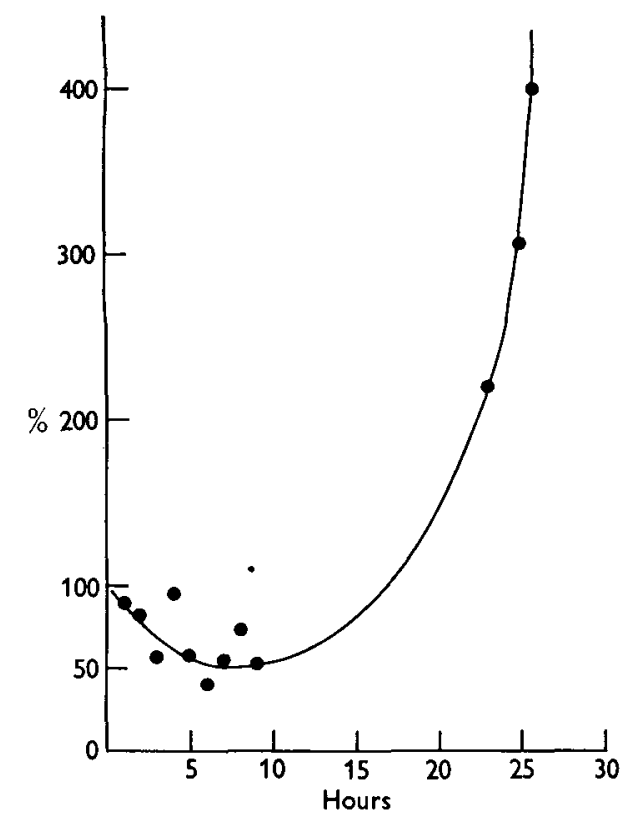

Fig. 5. Experiment 148.

Figs. 4-8. Growth curve of vaccinia virus in chick-embryo cell suspension incubated in a nutrient medium. 


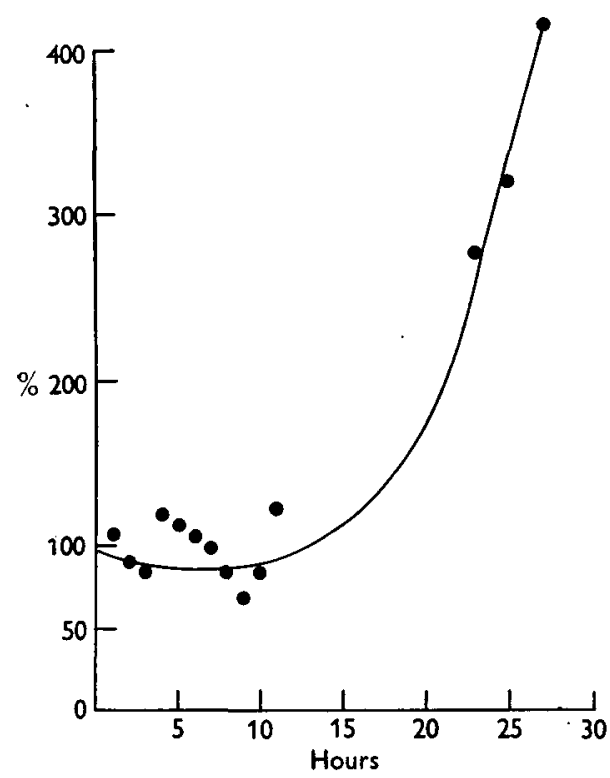

Fig. 6. Experiment 149.

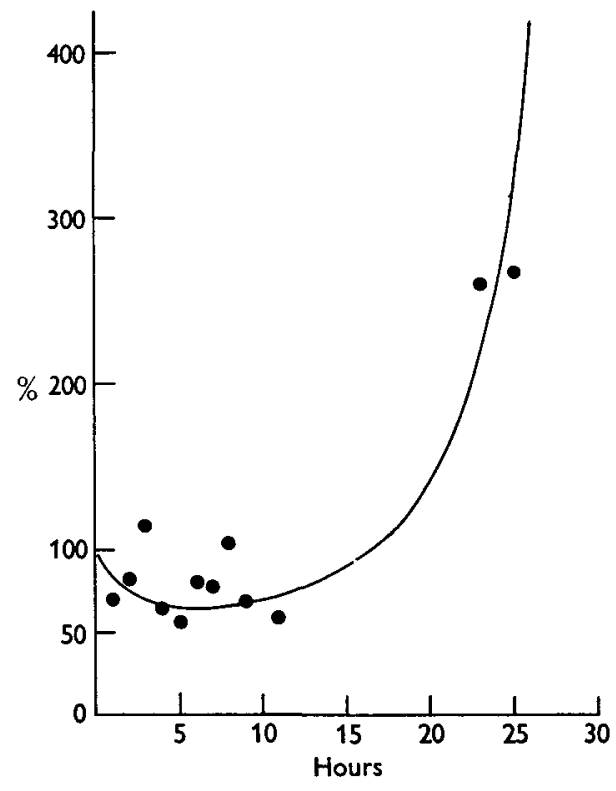

Fig. 7. Experiment 150.

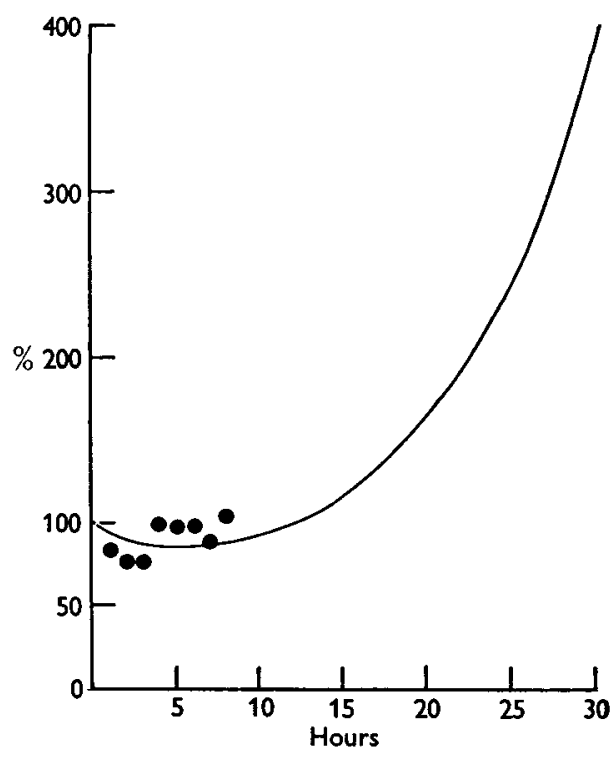

Fig. 8. Experiment 153.

\section{DISCUSSION}

An endeavour had been made in these experiments to obtain evidence for or against the view that the fall in titre of vaccinia virus in infected tissue which precedes multiplication of virus indicates a so-called 'eclipse phase', that is, a transformation of virus into a non-infective form in which state it is reproduced to be changed by a further process into mature and infective virus. The experiments have shown that the fall which occurs in the chorio-allantoic membrane in vivo was 
paralleled when infected membrane or minced chick-embryo was incubated in culture. This in itself is not sufficient to warrant the assumption that the loss of infectivity is due to an eclipse phase. Two further findings suggested caution in making such an assumption; a similar fall occurred in cultures with heated or disintegrated membranes in which the virus did not grow, and there was usually only a slight preliminary fall in titre in cultures of chick-embryo cell suspensions in which the virus multiplied.

The mechanism which accounts for fall in titre of the virus is not known, and conceivably one mechanism could operate in the case of living membranes and another in heated or disintegrated membranes. When virus was incubated at $37^{\circ} \mathrm{C}$. in Hanks' solution the loss of infectivity was rapid, about $1 \%$ remaining at $5 \mathrm{hr}$. Virus in heated membranes, incubated in Hanks' solution, fell to $20-30 \%$ of the original titre in $5 \mathrm{hr}$. and thereafter dropped much more slowly (Fig. 2), which might be regarded as a physicochemical effect of the tissue-protecting virus to some extent from the still more unfavourable conditions for survival in Hanks' solution itself. Disintegrated membranes might be regarded similarly. This, however, is speculation; the problem requires further investigation. The fact that the fall in titre occurring in living membranes and chick-embryo mince was so closely paralleled by that seen with the non-living tissue, suggested that the processes may be similar, and casts considerable doubt on the idea that the loss of infectivity of virus in the living tissue was part of a life-cycle of the virus concerned with its multiplication.

A different result was obtained with suspensions of chick-embryo cells; the preliminary drop in titre was virtually negligible in some experiments and in most of the others was relatively small, dropping to $65-70 \%$ of the original, a figure which in itself would not support decisively, the idea of an eclipse phase. The experiments, as will be noted, were not entirely uniform with regard to the amount of the preliminary fall in titre, but each experiment was complete in itself and those which showed only a negligible drop in titre have been too many to be disregarded as oddities. The general picture of all experiments with chick-embryo cell suspensions did not favour the interpretation that the drop in titre represented an eclipse phase.

The composition of the suspending medium affected the behaviour of virus in culture particularly when cell suspensions were used. Thus with Hanks' solution the virus grew in chorio-allantoic membrane and minced embryo but not in cell suspension; when chick-embryo extract was added to Hanks' solution it then supported the growth of virus in cell suspensions. This would suggest that something essential for growth of virus was removed during the preparation of cell suspensions and was replaced by 'embryo extract' in the medium. It is not known whether the effect of the medium was exerted directly on the virus or whether it was indirect through an effect on the cells.

Only one strain of virus, adapted to the rabbit skin, has been used for these experiments. It is possible that egg-adapted virus might behave somewhat differently, though it is hardly to be expected that the mechanism of its multiplication would be fundamentally different. The data set out in this paper do not 
settle the mechanism of growth of vaccinia virus and further analyses of its growth in cultures of different types are being made.

The studies by microscopy or electron microscopy of intracellular appearances during the growth of vaccinia virus (Bland \& Robinow, 1939; Bang, 1950; Wyckoff 1951 ; Peters \& Nasemann, 1953 ; Gaylord \& Melnick, 1953; Morgan, Ellison, Rose \& Moore, 1954; Noyes \& Watson, 1955; Flewett, 1956) suggests that new virus is formed in certain foci within the cell, and that the units of virus may not at first appear in their final form. But there is no certainty from morphological studies what happens to the virus in the earliest stages after a cell is infected. The tendency has been to assume that it becomes non-infective as an essential part of the process of virus reproduction. This may eventually turn out to be the case, but at present there is no conclusive evidence about it one way or the other. The results reported in this paper suggest that further evidence is required before coming to a final conclusion.

\section{SUMMARY}

The growth curve of rabbit skin-adapted vaccinia virus in the chick chorioallantoic membrane incubated in Hanks' solution showed a drop in titre of virus for about $10 \mathrm{hr}$. followed by growth. At least $25 \%$ of virus, sometimes more, remained infective. A similar fall in titre was observed in heated membranes in which the virus did not grow and this occurred also when membranes, either normal or heated, were infected and disintegrated before incubation.

The growth curve of virus in minced chick-embryo was similar to that in chorioallantoic membrane.

Virus in cell suspensions prepared from chick embryo and incubated in a nutrient medium showed only a small loss of infectivity before growth in some experiments and rarely dropped below $65-70 \%$ of the original titre in others.

These results throw considerable doubt on the view that loss of infectivity preceding growth of vaccinia virus should be interpreted as an essential part of a growth cycle.

\section{REFERENCES}

Anderson, S. G. (1954). The growth curve of vaccinia virus on the chorioallantois. Aust. $J$. exp. Biol. med. Sci. 32, 633.

BANG, F. (1950). Cellular changes in the chick chorio-allantoic membrane infected with herpes simplex and vaccinia. A study with thin sections for the electron microscope. Johns Hopk. Hosp. Bull. 87, 511 .

Bland, J. O. W. \& Robinow, C. F. (1939). The inclusion bodies of vaccinia and their relationship to the elementary bodies studied in cultures of the rabbit's cornea. J. Path. Bact. 48, 381.

Briody, B. A. \& Stannard, C. (1951). Studies on vaccinia virus. I. The development of haemagglutinating and infective particles in the chorioallantois of the chick embryo. J. Immunol. 67, 403.

Crawford, G. N. C. \& Sanders, F. K. (1952). The multiplication of vaccinia virus in tissue cultures of adult rabbit skin. Quart. J. micr. Sci. 93, 119.

Dulbecco, R. \& Vogt, M. (1954). Plaque formation and isolation of pure lines with poliomyelitis viruses. J. exp. med. 99, 167.

FLEwETT, T. H. (1956). Intracellular growth of some viruses of the pox group. An electron microscopic study of infected chick chorionic cells. J. Hyg., Camb., 54, 393. 
Gaylord, W. H. \& Melnick, J. L. (1953). Intracellular forms of pox viruses as shown by the electron microscope (vaccinia, ectromelia, molluscum contagiosum). J.exp. Med. 98, 157.

Hoagland, C. L., Smadel, J. E. \& Rrvers, T. M. (1940). Constituents of elementary bodies of vaccinia. I. Certain basic analyses and observations on lipid components of the virus. J. exp. Med. 71, 737.

Maitland, H. B. \& Tobin, B. M. (1956). The growth of vaccinia virus in the chorio-allantois of the developing chick embryo and the production of complement-fixing antigen and haemagglutinin. J. Hyg., Camb., 54, 102.

Morgan, C., Ellison, S. A., Rose, H. M. \& Moore, D. H. (1954). Structure and development of viruses observed in the electron microscope. II. Vaccinia and fowl pox viruses. J. exp. Med. 100, 301.

Noyes, W. F. \& Watson, B. K. (1955). Studies on the increase of vaccine virus in cultured human cells by means of the fluorescent antibody technique. J. exp. Med.102, 237.

Peters, D. \& Nasemann, T. (1953). Untersuchungen am Virus der Variola-Vaccine. II. Mitt. Nachweis von Elementarkörperstadien mittels enzymatisch-elektronenoptischen Analyse. Z. Naturf. $8 \mathrm{~B}, 547$.

Wyckoff, R. W. G. (1951). The virus of vaccinia in chick embryo membrane. Proc. nat. Acad. Sci., Wash., 37, 565.

(MS. received for publication $30 . \mathrm{x} .56$ ) 